\title{
ROCK E RESISTÊNCIA NA AMÉRICA LATINA
}

\author{
Gérson Werlang ${ }^{1}$
}

Resumo: No contexto latino-americano das décadas de 1960 e 1970, o rock aparecia como um gênero malquisto pelo establishment. Convivendo com ditaduras militares que tolhiam praticamente qualquer forma de expressão que atingisse não apenas os aspectos políticos, mas também a moral "e os bons costumes", o rock propõe uma resistência por vias múltiplas, tanto presente em seu conteúdo, como na sua forma, no seu conteúdo outsider e estranho, para usar o conceito de Zygmunt Bauman, incluindo aí o modo de vestir e a liberdade de experimentar. Este ensaio se propõe a analisar brevemente a resistência no rock latino-americano no contexto ditatorial na Argentina, no Brasil e no Chile.

Palavras-chave: rock; resistência; América Latina.

Abstract: In the Latin American context of the 1960s and 1970s, rock appeared as a genre disliked by the establishment. Coexisting with military dictatorships that hampered virtually any form of expression that affected not only political aspects, but also morals "and good customs", rock proposes a resistance in multiple ways, both present in its content and in its form, in its outsider and strange content, to use Zygmunt Bauman's concept, including the way of dressing and the freedom to experiment. This essay aims to briefly analyze the resistance in Latin American rock in the dictatorial context in Argentina, Brazil and Chile.

Keywords: rock; resistance; Latin America.

1 Músico e escritor. Mestre em Música pela University of Miami, EUA. Doutor em Letras pela Universidade Federal de Santa Maria. Professor do Departamento de Música e do Programa de Pós-Graduação em Letras da UFSM. 


\section{Introdução}

A contracultura ${ }^{2}$ eclodiu como um movimento global da juventude no final da década de 1960, direcionando os protestos contra a Guerra do Vietnã e a luta pelos direitos civis tanto na Europa quanto nos Estados Unidos. Dentro desse contexto, a música, e mais especificamente o rock, foi um dos veículos mais fortes de expressão do período. Surgido em meados da década de 1950, o rock trazia o sentido de contestação em sua gênese.

$\mathrm{Na}$ América Latina, embora o rock chegasse em tempos diferentes (no Brasil, desde os anos cinquenta, no Chile e Argentina, nos anos sessenta) ele encontraria ecos contraculturais a partir do fim dos anos sessenta, e com características próprias se comparado ao cenário de Europa e Estados Unidos, já que vários países latino americanos passavam por contextos ditatoriais.

Este ensaio propõe uma análise do rock produzido em alguns países da América Latina, notadamente o Brasil, a Argentina e o Chile, nas décadas de sessenta, setenta e oitenta, e como essa produção musical ligada à contracultura gerou características peculiares, diferenciadas do eixo EUA/Europa, principalmente devido ao fato de que ele representava uma forma de resistência às ditaduras militares que grassavam o continente.

\section{O contexto de surgimento do rock}

O ano mais comum dado como de surgimento do gênero é 1955, quando a transição e mescla do rhythm and blues, da country music e do gospel negro, já estão sedimentados para formar o novo gênero. A veiculação do mesmo para uma juventude formada por brancos e negros fez com que se rompesse o caráter de nicho ocupado pelo blues, música negra que era vendida e veiculada principalmente para os negros. Esse fato primordial forjou um gênero nascido sob o signo do rompimento de barreiras sociais e, portanto, sob a égide revolucionária que o caracterizaria.

Inicialmente batizado de rock and roll, termo de conotações variadas, mas com tinturas sexuais, o estilo rapidamente ganhou as rádios e um público ardoroso entre a juventude dos Estados Unidos dos anos 1950. Os principais artistas do início do movimento foram Bill Haley, Chuck Berry, Fats Domino, Little Richard, Jerry Lee Lewis e Elvis Presley.

O caráter multirracial do novo gênero desagradou os setores mais conservadores da sociedade estadunidense, e reações políticas orquestradas tentaram dar um fim ao movimento. Chuck Berry foi preso, assim como Jerry Lee Lewis. Elvis Presley foi mandado para o exército, e nunca mais seria o mesmo em termos de significância para o movimento. Little Richard foi duramente perseguido, o que o levou à situação extrema de assumir um posto como pastor da Igreja Batista para se afastar do centro dos acontecimentos. Desde o inicio, a

2 A contracultura pode ser definida como uma oposição à cultura tecnocrática dominante e rejeitava os discursos políticos tradicionais, fossem eles de direita, centro ou esquerda, por serem entendidos como inteiramente agregados a uma cultura dominante. O termo "contracultura" é, portanto, significativo para entender atos desviantes em épocas de revolta juvenil, como foram os anos finais da década de 1960. Trabalhos importantes nessa área são os de John Milton Yinger, intitulado Counterculture and subculture (1960), e The making of a conter culture (1969), de Theodore Roszak, publicado na efervescência dos eventos (SAGGIORATO, 2021, p. 16). 
preocupação das autoridades conservadoras era com a questão comportamental, que gerava uma abertura política numa juventude que, até aquele período, era bastante submissa aos desejos dos pais. Segundo Lonza:

O novo som parece se identificar mais com os adolescentes que, desta vez, tem uma arma diferente para fazer valer suas ideias. A velha guarda, porém, reage e taxa o novo som de demoníaco e incontrolável. Mas é inútil. O comportamento da juventude já é outro, suas roupas são diferentes das dos pais (LONZA, 1995, p. 10).

O que parecia ser uma diferença superficial carregava consigo uma teia de significados. O rock, no seu início, já trazia a rebeldia em seu seio, mas era uma rebeldia sem direcionamento. Esse período é conhecido como o da "rebeldia sem causa", cuja formatação social bebia em fontes outras, mesmo alheias ao nascente rock 'n' roll, como o cinema, nos filmes de James Dean (que ofereceu uma imagem pública ao rebelde sem causa), e Marlon Brando, particularmente no filme O selvagem, de $1953 .^{3}$

\section{O dia em que o rock morreu e a ascensão do rock inglês}

Em torno do ano de 1958, as grandes lideranças do momento inicial do rock estavam fora de combate, e foram substituídos pelo establishment por figuras que eram reflexos pálidos e pré-fabricados dos originais. Um bom exemplo é o do cantor Pat Boone, que fazia versões de clássicos do período dirigidas ao público branco. Boone era orientado a fazer versões assexuadas e bem comportadas de músicas de elevado teor erótico, e apropriou-se de canções como Tutti-Frutti, de Little Richard, um cantor e compositor negro de grande importância e expressão no início do rock'n'roll. Todo o erotismo e a malícia presentes no original da canção foi substituído por uma versão quase destituída de apelo sexual. Para piorar a situação, a versão de Boone superou a do compositor em termos de sucesso comercial. Boone, hoje, é um comentarista político e religioso pentecostal conservador de ultra-direita.

Nesse contexto pouco favorável, o surgimento de três figuras inovadoras deu um sopro de renovação num movimento musical que parecia se esvair. Eram eles: Buddy Holly, Big Bopper e Ritchie Valens.

Ritchie Valens, cujo verdadeiro nome era Richard Stevens Valenzuela, filho de imigrantes mexicanos, foi o primeiro nome latino do rock, e o primeiro a dar expressão musical, ainda que tímida, aos anseios da comunidade latina dentro dos EUA. Big Bopper ${ }^{4}$ adicionou elementos humorísticos ao rock daquele momento, alargando as sua possibilidades expressivas.

\footnotetext{
3 Título original: The Wild One. Dirigido por László Benedek, baseado num conto, The cyclists raid, do escritor Frank Rooney. Curiosamente, o filme apresenta uma trilha sonora engessada e formal, composta para orquestra, no momento exato em que a sua trilha ideal, o rock and roll, está surgindo.
} 
Dos três, o nome de maior expressão era o de Buddy $\mathrm{Holy}^{5}$, que desenvolveu novas formas expressivas no rock do período, dando continuidade ao gênero. Buddy era uma das grandes esperanças do futuro do rock depois da saída de cena dos primeiros artistas, e conseguiu exercer enorme influência numa juventude sedenta de ídolos musicais. Essa influência, como já foi dito, terminava por exercer outros tipos de ação sobre a juventude, principalmente em termos comportamentais e de questionamento do establishment vigente.

Essa esperança de renovação do rock terminou de forma trágica. Segundo Fernando Rosa:

Dali a cerca de um ano, veio o golpe de misericórdia na rebeldia juvenil, quando um avião Beechcraft Bonanza de quatro lugares caiu, depois de decolar do aeroporto de Mason City, em Iowa, nos Estados Unidos. Era 3 de fevereiro de 1959, e o acidente que matou Buddy Holly, Ritchie Valens e Big Bopper ficou conhecido na mitologia pop como "o dia que o rock morreu" (ROSA, 2005, p. 53).

O evento teve múltiplas consequências, desde um impulso ao rock fora dos Estados Unidos, principalmente na Inglaterra, onde ganharia cada vez mais força, escapando ao poder da censura norte-americana; até a ilusão inicial de vitória dos meios conservadores dos EUA, com um processo que Rosa (2005, p. 55) chama de "sanitização" conservadora, que atingiu não apenas o rock, mas também a literatura, o cinema e os quadrinhos.

\section{O rock contra o racismo}

Uma das questões centrais do princípio do rock 'n' roll é a não aceitação dos meios conservadores norte-americanos da relação multirracial existente tanto na música, quanto no comportamento do público. Essa mistura de brancos e negros nos shows, num compartilhamento democrático de espaços, numa relação de aceitação e tolerância, tocou num ponto sensível de organizações fascistas como a Ku Klux Klan ${ }^{6}$.

Esta questão, com tensionamentos e manifestações de congressistas ultraconservadores, promovendo a destruição de discos dos artistas e o recrudescimento da perseguição aos mesmos, teve uma espécie de desfecho histórico num evento acontecido em meados de 1960.

Um show com vários artistas em uma cidade do interior dos EUA, capitaneado por um disc-jockey negro, Steve "The Playboy" Shelley, foi interrompido porque seu conteúdo, um show de rock'n'roll, era considerado inadequado para jovens brancos. Segundo Alexandre (2005):

(...) quem apareceu no palco foi o dono do principal clube de Bessemer (Carolina do Norte), Ray Mahoney: "Senhoras e senhores, desculpem pelo imprevisto, mas há 80 membros da Ku Klux Klan do lado de fora do prédio e eles não acham que

5 Nome artístico de Charles Hardin Holley (1936-1959).

6 Organização criminosa de extrema-direita nascida no sul dos Estados Unidos, em fins do século XIX. Usavam roupas brancas encapuzadas e promoviam linchamentos e a tortura dos que julgavam seus inimigos. Suas principais características são o racismo, defesa da supremacia branca, anti-comunismo e pentecostalismo anti-católico. Com o trumpismo, braços da KKK renasceram em várias partes dos Estados Unidos. 
Steve Shelley seja bom o suficiente para vocês. O show não vai poder acontecer". Foi quando, para o espanto do próprio DJ, 800 daqueles jovens brancos romperam para fora do clube e partiram para os sopapos contra os encarapuçados racistas. "Era inacreditável ver aqueles adolescentes brancos literalmente salvando minha vida", lembraria Shelley. Depois de 14 de julho de 1960, quem não entendesse a transformação que o rock produzira na sociedade, ou não compreendera nada, ou não gostava do que ouvia (ALEXANDRE, 2005, p. 59).

Ainda, segundo Barcinsky (2004), "a simbologia do fato é forte demais: brancos lutando contra brancos, pelo direito de ouvir música negra." O acontecimento de Bessemer é hoje considerado um ponto crucial de amadurecimento social do rock, e ponto de entrada para os movimentos contraculturais dos anos sessenta. O rock, de rebelde sem causa, ganhava uma motivação, que nortearia as cada vez mais complexas buscas sociais e existenciais de fins da década de 1950 e início da seguinte.

\section{O rock cruza o oceano}

Enquanto as autoridades conservadoras norte-americanas tentavam sufocar o rock'n'roll, uma nova geração, fora dos Estados Unidos, sentia a sua influência. No Reino Unido, particularmente em cidades portuárias como Liverpool, ou industriais, como Birmingham, o rock encontraria condições para a fermentação do estilo fora dos EUA, principalmente pela identificação de uma juventude proletária com os anseios sociais e a rotina de sofrimento presentes no blues, uma das raízes do rock'n'roll.

Com o surgimento dos Beatles e a subsequente explosão da Beatlemania ${ }^{7}$ o rock inglês começa a ganhar o mundo, num fenômeno que ficou conhecido como Invasão Inglesa. Bandas britânicas como Rolling Stones, The Kinks, The Animals e dezenas de outras ganham espaços nas rádios e mídia norte-americana, transformando a história da música e dos costumes nos EUA.

Depois de dois anos de Beatlemania, as coisas começaram a ficar tensas para os Beatles. O papel de queridinhos da mídia começou a incomodá-los e um novo caminho fez-se necessário. As temáticas das canções do grupo, em seu período inicial, abordavam principalmente relacionamentos amorosos, sem dar espaço a outras questões. A insatisfação atingiu novos níveis quando John Lennon e Paul McCartney começaram a ver seus contemporâneos experimentarem voos mais altos.

O encontro dos dois com Bob Dylan também deu aos dois principais compositores do grupo, mas principalmente a John, a consciência de que não abordavam em suas canções grandes temas ligados a toda a efervescência que ocorria à sua volta. Essa insatisfação ganhou voz em Help!, quinto disco da banda, principalmente em sua canção título. A partir dali a banda rapidamente expandiria seus horizontes rumo à contracultura, carregando toda uma geração com ela.

7 Beatlemania: fenômeno acontecido primeiramente no Reino Unido e depois nos Estados Unidos, espalhando-se em seguida para outras partes do mundo. Os Beatles, entre a histeria dos fãs e a superexposição midiática, arrastam multidão aos seus shows e às lojas de discos, e tornam-se um fenômeno artístico-social sem precedentes na cultura pop. 
À medida que as lutas sociais ganhavam voz na década de 1960, com a ascensão do movimento hippie, os protestos contra a Guerra do Vietnã, o início das lutas ecológicas e de liberação sexual, o rock era a trilha sonora de todos esses movimentos e principal meio artístico de expressão dos mesmos.

O rock, na década de 1960, ganha, portanto, consciência social e evolui de uma forma de entretenimento para uma forma de arte, e sua influencia se expande a diversos países levando consigo esses anseios.

Nascido em uma cultura de massa, produz uma forma de arte que, embora popular e com muitos admiradores, não se sujeita à cultura de massa. É o que Saggiorato (2021) chama de produção de "atos desviantes": "As pessoas que cometem atos desviantes e que, em consequência, acabam desterritorializando o território identitário e cultural pré-estabelecido podem ser chamados de outsiders ou estranhos" (SAGGIORATO, 2021, p. 23).

Os outsiders, chamados de estranhos por Zygmunt Bauman, são pessoas que "não se encaixam no mapa cognitivo, moral ou estético do mundo (...) deixam turvo o que deve ser transparente, confuso o que deve ser uma coerente receita de ação, e impedem a ação de ser totalmente satisfatória" (BAUMAN, 1998, p. 27). Esse rompimento lento e difuso das fronteiras dá espaço aos atos desviantes da contracultura. São atos que podem ser alcançados pela insatisfação com a realidade vigente, a partir da geração de um ambiente que crie um espaço antagônico ao real. Tanto os outsiders quanto os atos desviantes surgem como resistência a um mundo que contém contradições éticas geradoras de questionamentos, mas onde esses outsiders ou estranhos são uma minoria que quer se afastar, que não pode aderir àquele sistema.

Essas definições são profundamente apropriadas quando descrevem o público e os artistas de rock latino-americanos das décadas de sessenta e sessenta do século XX. O meio não favorecia àquele tipo de criação artística e, ao contrário dos EUA e Europa, o estímulo era inexistente ou limitado. Além do mais, viviam uma repressão muito mais intensa do que a vivida nos territórios estadunidense e europeu, devido à existência de ditaduras militares em seus países. Ser outsider, para esses artistas, era uma forma de sobrevivência em meio ao caos.

\section{Rock e contracultura na América Latina}

Chegada do rock na América Latina deu-se de forma desigual, em termos cronológicos. No Brasil, ele chegou em sua primeira hora, ainda na década de 1950, como um modismo, é certo, mas com força suficiente para chegar à década seguinte e alçar voos mais altos.

$\mathrm{Na}$ Argentina, ele chegou na década de 1960, e no Chile um pouco depois, em meados da década de 1960, na onda do sucesso dos Beatles. Nosso sobrevoo sobre a produção roqueira de três países latino-americanos: Brasil, Chile e Argentina, é necessariamente algo panorâmico, devido às limitações deste ensaio, que propõe-se breve. Vale dizer que diversos outros países latino-americanos tiveram suas produções roqueiras e passaram por situações similares, em muitos casos, mas também peculiares a suas regiões e culturas. 


\section{Rock, censura e resistência no Brasil}

A contracultura chega ao Brasil num reflexo direto do que acontecia na Europa e EUA, já em fins da década de 1960. Um dos primeiros reflexos da contracultura no Brasil foi a Tropicália ou Tropicalismo ${ }^{8}$. Segundo Saggiorato:

A Tropicália (...) foi um movimento cultural brasileiro influenciado pelas correntes artísticas de vanguarda e pela cultura pop. Introduziu manifestações tradicionais da cultura brasileira em inovações estéticas radicais (...) e também influenciou as artes plásticas, cinema e teatro brasileiro (SAGGIORATO, 2021, p. 27).

A Tropicália escancararia as portas da música brasileira para os novos sub-estilos de rock que despontavam no cenário internacional, ao mesmo tempo em que daria legitimidade para os inúmeros cruzamentos estilísticos que o rock dos anos setenta produziria no Brasil. De certa forma, foi a partir da Tropicália que as gravadoras se modernizaram, o que abriu as portas para a chegada de grupos que são essenciais neste estudo, como Mutantes, Secos \& Molhados, O Terço e muitos outros.

O advento da contracultura no Brasil teve, no entanto, características diversas das encontradas no eixo Europa/EUA. Segundo Christopher Dunn (apud Saggiorato):

\footnotetext{
Enquanto a contracultura nos Estados Unidos explodiu no contexto das lutas pelos direitos civis, Guerra de Vietnã e descontentamento com a sociedade industrial moderna, as contraculturas latino-americanas surgiram em resposta à moral conservadora da Igreja Católica, à estrutura patriarcal da família, aos governos autoritários e, em alguns casos, ao impacto da insurgência revolucionária (DUNN apud SAGGIORATO, 2021, p. 28).
}

Reiterando a citação de Dunn, gostaríamos de ressaltar esse aspecto, desde já, de resistência aos governos autoritários, presente tanto no Brasil quanto em outros países latino-americanos.

\section{Lá vem o Guarda Belo}

Como os grupos de rock reagiram a uma situação ditatorial, extremamente conservadora e repressiva? Com música e letras que tentavam driblar a censura ao mesmo tempo em que apontavam caminhos, numa linguagem muitas vezes altamente figurada. Mas, aqui cabe uma observação, não apenas a letra era revolucionária, também a música. As características do rock brasileiro do período contém uma atitude outsider, regida pelos atos desviantes que desterritorializam e reinventam os sons, fugindo da cultura de massas e pro-

8 O Tropicalismo foi um "movimento musical que teve lugar a partir de 1967, liderado por Caetano Veloso e do qual participaram Gilberto Gil, Tom Zé, Torquato Neto, Capinam, Rogério Duprat, Damiano Cozzella, Júlio Medaglia, o grupo Os Mutantes, Gal Costa e Rogério Duarte, entre outros. O movimento ressaltou os contrastes da cultura brasileira e absorveu vários gêneros musicais, como samba, bolero, frevo, música de vanguarda e o pop-rock nacional e internacional" (ALBIN, 2006, p. 752). 
vocando uma nova forma artística. Essa característica, apontada no brilhante trabalho de Alexandre Saggiorato (2021) sobre o rock brasileiro dos anos sessenta e setenta, é algo que pode ser estendido para o rock latino-americano do período. Também no Chile e na Argentina, desenvolveram-se sonoridades desviantes, ligados a características locais.

No Brasil, um bom exemplo é a música “Assim assado”, do Secos \& Molhados, ${ }^{9}$ presente no primeiro disco do grupo, de 1973. A canção, composição de João Ricardo, começa de forma ambígua, quase uma canção infantil:

\author{
São duas horas \\ da madrugada \\ de um dia assim \\ Um velho anda \\ de terno velho \\ assim assim \\ Quando aparece o guarda belo \\ (SECOS \& MOLHADOS, 1973, LADO B, FAIXA 1)
}

Como muitas canções da época no Brasil, a letra contém uma série de elementos que escamoteiam e ocultam seu sentido mais direto. A estratégia de uma abordagem que lembra uma história infantil deixa entrever, no entanto, duas figuras, um velho e um guarda noturno. A hora ("duas horas da madrugada"), num estado de exceção, entrega o autoritarismo do regime. Para regimes militares, noite alta, alguém andando pela rua, só pode ser algo subversivo.

A figura do guarda é ironizada. Outra estratégia lírica, o guarda belo (Belo?). O velho apenas está passando pelo local, mas é interpelado pelo guarda.

\author{
É posto em cena \\ fazendo cena \\ um treco assim \\ bem apontado \\ ao nariz chato \\ assim assim \\ Quando aparece a cor do velho \\ (SECOS \& MOLHADOS, 1973, LADO B, FAIXA 1)
}

"Um treco assim" escamoteia a arma ou cassetete que o guarda usa para interpelar o

9 Grupo musical formado originalmente por João Ricardo (voz, violões, harmonica e principal compositor), Ney Matogrosso (voz), Gerson Conrad (voz e violões), Marcelo Frias (bateria e percussão), além de outros músicos que transitavam em torno do núcleo criativo. 
velho. O extremo entre as figuras é ressaltado pela repetição e pelo exagero. A interpelação armada, o cassetete ou similar "bem apontado ao nariz chato", e a reação inesperada e indefesa do velho, que simplesmente cora (ou sangra?). Ou, ainda, revela a cor (negra?) do velho. As possibilidades, todas, cercam o tema central: autoritarismo, repressão, a possibilidade de racismo. E não existe possibilidade de escape:

\author{
Mas guarda belo \\ não acredita \\ na cor assim \\ ele decide \\ no terno velho \\ assim assim \\ Porque ele quer o velho assado \\ (SECOS \& MOLHADOS, 1973, LADO B, FAIXA 1)
}

O desfecho é peculiar. O ritmo da canção, a instrumentação, o tom infantil da narrativa, induzem o ouvinte a algo leve, enquanto a mensagem é de extrema violência, uma denuncia contra o estado de coisas à época.

\author{
Mas mesmo assim \\ o velho morre \\ assim assim \\ e o guarda belo \\ é o herói \\ assim assado
}

Porque é preciso ser assim assado

(SECOS \& MOLHADOS, 1973, LADO B, FAIXA 1)

A canção finaliza com a morte do velho, mas "o guarda belo é o herói assim assado". Os crimes da ditadura invariavelmente ficavam impunes, sem possibilidade de recurso, mudança ou outra interpretação, "porque é preciso ser assim assado".

\title{
Rock e resistência na Argentina
}

Uma abordagem semelhante à dos Secos \& Molhados, embora diferente, foi utilizada pela banda argentina Serú Girán ${ }^{10}$, na Canción de Alícia en el país, presente em seu disco Bicicleta, de 1980. Ao utilizar uma citação explicita de um clássico da literatura para crianças,

10 Banda argentina formada por Charly Garcia (voz, teclados, guitarra), David Lebón (guitarras e voz), Pedro Aznar (baixo e voz) e Oscar Moro (bateria). Esteve ativa entre 1978 e 1982 (NAHOUM, 2005, p. 234). 
Alice no País das Maravilhas ${ }^{11}$, a canção dá um tom de fábula a um tema que não poderia ser abordado explicitamente: a alienação, o exílio, a violência do regime militar argentino em fins da década de 1970.

A letra propõe uma conversa com a menina Alice, a personagem central do romance de Carroll:

Quién sabe, Alicia, este país no estuvo hecho porque sí...

Te vas a ir, vas a salir, pero te quedas

¿dónde más vas a ir?

Y es que aquí sabes el trabalenguas trabalenguas,

el asesino te asesina, y es mucho para tí.

Se acabó ese juego que te hacía feliz...

(SERÚ GIRÁN, 1980, LADO A, FAIXA 3).

A ironia e a crítica ao momento vivido já começa com o título, onde a palavra maravilhas é suprimida, restando apenas Alice no País. As imagens, a maior parte derivadas do livro de Lewis Carroll, estabelecem um diálogo com o momento histórico.

"Donde más vas a ir?", ecoa os perseguidos, os exilados, os que não tem para onde fugir. Os jogos de trava-línguas que Alice tanto gosta ecoam a censura, porque senão "el asessino te assesina". A canção, um testemunho de enorme coragem no momento em que milhares desapareciam e eram assassinados pela ditadura argentina, aproveita os interstícios imagéticos e a multiplicidade de significados, algo inerente à obra de Carroll, para produzir novos significados.

\section{La Máquina de Hacer Pájaros}

Um grupo anterior ao Serú Girán, outro projeto de que participa Charly Garcia, é La Máquina de Hacer Pájaros ${ }^{12}$, em cujo segundo disco, chamado Películas, gravado e lançado no ano de 1977, há uma canção emblemática do período ditatorial argentino. Trata-se da canção que dá título ao disco, "Películas", que contém um título complementar posterior, entre parênteses, "Películas (Qué Se Puede Hacer Salvo Ver)”. Esse "que se pode fazer, senão assistir filmes", direciona todo o disco, que culmina na canção que lhe dá título.

11 Alice's Adventures in Wonderland, do escritor Lewis Carroll, pseudônimo literário de Charles Lutwidge Dodgson (1832-1898), publicado pela primeira vez 1865. Lutwige era uma matemático euclidiano e catedrático em Oxford, mas seu pseudônimo o ultrapassou, com uma literatura que supera o epíteto de infanto-juvenil, dada sua beleza e complexidade (STOFFEL, 1997).

12 Banda argentina de rock progressivo, formada por Charly García (voz, teclados), Oscar Moro (bateria e percussão), Carlos Cutaia (teclados), Gustavo Bazterrica (guitarras) e José Luis Fernández (baixo). Esteve ativa de 1975 a 1977 (NAHOUM, 2005, p. 161). 
O álbum é uma obra conceitual ${ }^{13}$, e há diversas citações que lembram uma trilha sonora, com seu clima às vezes tenso, às vezes relaxado ou mesmo blasé. Esse distanciamento do que se esperaria de um disco de rock já provoca uma espécie de afastamento do que realmente trata a obra, cuja temática central é o desespero, causado pelo rumo que a situação política toma naquele momento na Argentina.

A canção "Películas", de autoria de Charly García e Carlos Cutaia, narra, a partir de um personagem que assiste filmes, uma situação de aparente rotina e normalidade. O narrador-personagem nos apresenta uma imagem, de um filme em que aparece uma atriz e seu carro conversível:

Películas (Qué Se Puede Hacer Salvo Ver)

Ella es una actriz, se seca y mira el mar, se viste de plata, nadie la viene a buscar, no espera que toquen el timbre se monta en un convertible y se va, ya verán. ${ }^{14}$

É interessante notar que, musicalmente falando, a música corre fácil, numa verve levemente jazzística, como fosse uma trilha sonora de filme. É despretensiosa, não há arroubos vocais, que se mantém numa linha melódica intermediária, sem grandes saltos melódicos, com uma exceção, um grito em glissando que ocorre em meio aos versos. A canção segue e revela, subitamente, o desencanto:

Que se puede hacer salvo ver películas, sueño con la actriz que se seca y mira el mar, mi corazón es de ella, mi mente está en las estrellas ${ }^{15}$.

Além do desencanto, a fuga da realidade imediata através do filme, já que o narrador "sonha com a atriz que se seca e olha o mar". A evasão se completa: "meu coração é dela, minha mente está nas estrelas". Tal estado de alienamento não entrega a situação real do personagem/narrador da canção. A sutileza da cena oculta as razões verdadeiras. Como ocorria no Brasil, quanto menos explícito, melhor, é preciso escapar aos liames da censura ditatorial. O personagem sai de casa, passeia pela rua e vê a atriz do filme:

13 Obra conceitual: álbum musical em que todas as músicas estão interligadas por um mesmo tema. É uma das características do rock progressivo, estilo surgido na segunda metade dos anos 1960, e que desenvolveu grandes obras na primeira metade da década de 1970, onde teve seu apogeu comercial.

14 "Ela é uma atriz, se seca e olha o mar/Se veste de prata, ninguém vem lhe buscar/Não espera que toquem a campainha/Sobe num convertível e vai, já verão" (tradução minha).

15 "Que se pode fazer, senão ver filmes/sonho com a atriz que se seca e olha o mar/meu coração é dela/minha mente está nas estrelas” (tradução minha). 
Sobre la T.V. se duermen mis dos gatos

salgo a caminar para matar el rato

y de pronto yo la veo entre los autos

justo cuando la luz roja cierra el paso

me acercaré al convertible

diré: "quiero ser libre, llévame, por favor" ${ }^{16}$

Em meio à cena, quase cotidiana, quase normal, à visão da atriz (real ou imaginada?) o desabafo: "quero ser livre, leva-me, por favor" (LA MÁQUINA DE HACER PÁJAROS, 1977, LADO 1, FAIZA 4).

\section{Rock e resistência no Chile}

O rock no Chile começou tardiamente, comparado ao Brasil. As primeiras bandas começaram suas atividades já nos anos sessenta, fazendo covers dos Beatles. Desse estado de coisas, evoluem rapidamente para produções originais.

Os recursos técnicos eram extremamente escassos, mesmo se comparados ao Brasil. Faltavam instrumentos musicais, equipamentos para amplificação da voz, etc. Enfim, o manancial instrumental existente no país era preparado para a música folclórica e clássica, não para o rock. E fazer rock sem guitarras era algo difícil de imaginar. Esse período é hoje conhecido como uma espécie de período heroico do rock chileno, com algumas histórias folclóricas, embora verdadeiras, como a de um guitarrista que almejava comprar um bom instrumento e conseguiu convencer a esposa a viajar sozinho em sua lua de mel, que seria em Nova York, para poder trazer uma guitarra elétrica de boa qualidade dos Estados Unidos. A esposa convencida, o músico retornou da viagem com a primeira Fender Stratocaster ${ }^{17}$ a existir no Chile.

\section{Ditadura no Chile}

A ditadura militar no Chile inicia em 1973 através de um golpe militar coordenado pelo General Augusto Pinochet. Após o golpe, que levou ao assassinato do presidente Salvador Allende, Pinochet assumiu o controle do país com poderes absolutos, num dos regimes mais violentos e repressivos do período, mesmo levando em consideração outros regimes latino-americanos.

Houve milhares de mortos e desaparecidos. O golpe militar chileno foi perpetrado contra um dos regimes democráticos mais estáveis do continente, o do presidente Salvador Allende. O regime durou até 1990.

16 "Sobre a TV dormem meus dois gatos/Saio a caminhar para matar o rato/E logo eu a vejo entre os carros/Justo quando a luz vermelha cerra o passo/Me aproximarei do conversível/Direi: "quero ser livre, leva-me, por favor" (tradução minha).

17 Uma das guitarras pertencente ao rol dos instrumentos clássicos do gênero. Criada por Leo Fender em 1954, com o auxílio dos luthiers Geroge Fullerton e Freddie Tavares, tornou-se um dos instrumentos icônicos do rock, utilizado por guitarristas como Jimmy Hendrix, David Gilmour e Jeff Beck, entre muitos outros. 


\section{Victor Jara}

Uma das figuras de proa do período que envolve música e o contexto da ditadura foi o cantautor Victor Jara. Embora não possa ser considerado um cantor de rock, Victor está inserido nesse contexto através da folk music de protesto, que no cenário internacional incluía figuras como Bob Dylan e Joan Baez.

De origem camponesa, Victor Jara assume um pouco desse papel em sua obra, que denuncia as mazelas sociais e as desigualdades de um país desigual, através do movimento que ficou conhecido como Nueva Canción Chilena. Quando o regime de Pinochet se estabeleceu, Victor Jara foi um dos primeiros assassinados pela ditadura, tendo sido preso, torturado e fuzilado.

\section{Los Jaivas}

Los Jaivas é uma banda chilena formada em 1969, e que surge na onda da influência do rock progressivo e da psicodelia inglesa de fins dos anos sessenta. Uma das características marcantes do grupo, e um elemento altamente original, é a utilização do folclore andino mesclado ao rock.

Lançou seu primeiro disco em 1971. Desde o princípio, as influências da contracultura foram centrais em seus temas. Na esteira das influências pós-Woodstock, o grupo explorava temáticas como Yoga e meditação, a possibilidade de uma união colaborativa entre os povos, que diminuíssem a desigualdade, a partir de uma perspectiva sul-americana.

Depois dos primeiros movimentos do regime de Pinochet, pressentindo o perigo, o grupo abandonou o país, indo morar primeiramente na Argentina, e depois do recrudescimento da ditadura argentina, "passa uma boa parte de sua carreira exilado na França, onde lança a maioria de seus discos" (NAHOUM, 2005, p. 134). Dali, ganha projeção internacional, e consegue uma plataforma artística de resistência ao regime que proporcionou o surgimento de uma de suas obras primas, o disco Alturas de Macchu Picchu, onde as letras são de Pablo Neruda. Uma dessas canções é Sube a Nacer Conmigo Hermano:

Sube a Nacer Conmigo Hermano

Sube a nacer conmigo hermano

Dame la mano desde la profunda zona

De tu dolor diseminado

No volverás...del fondo de las rocas

No volverás...del tiempo subterráneo.

Este poema de Neruda, que ganha na canção dos Jaivas tons evocativos e proféticos, é um dos pilares de Alturas de Macchu Picchu, onde a fé na união por mundo melhor, temática cara a Neruda, é brilhantemente musicalizada pela banda, dando um corpo harmônico, tímbrico e melódico à letra. 
Todo o álbum contém uma ressonância cósmica que caminha junto com questões sociais. A letra segue:

No volverá...

tu voz endurecida

No volverán...

tus ojos taladrados....

Sube a nacer conmigo Hermano ${ }^{18}$

(LOS JAIVAS/NERUDA, 1981, LADO B, FAIXA 3)

O poema é um chamado aos homens mais simples, camponeses, lavradores, tecelões, para que participem da luta por um mundo mais justo, e, em última análise, saiam de sua condição servil. A música também é baseada em bases populares, unindo o rock aos ritmos folclóricos dos Andes, criando uma sonoridade muito particular, de múltiplos significados. Os sons da contracultura encontram o folclore sul-americano, os sons desviantes recriam possibilidades expressivas.

Gravando longe de casa, num exílio doloroso, os Jaivas conseguiram forjar uma obra que resistia à ditadura vigente, longe das garras de Pinochet. A obra não é apenas símbolo de resistência à situação política. Em sua qualidade e transcendência, também é símbolo de resistência ao tempo.

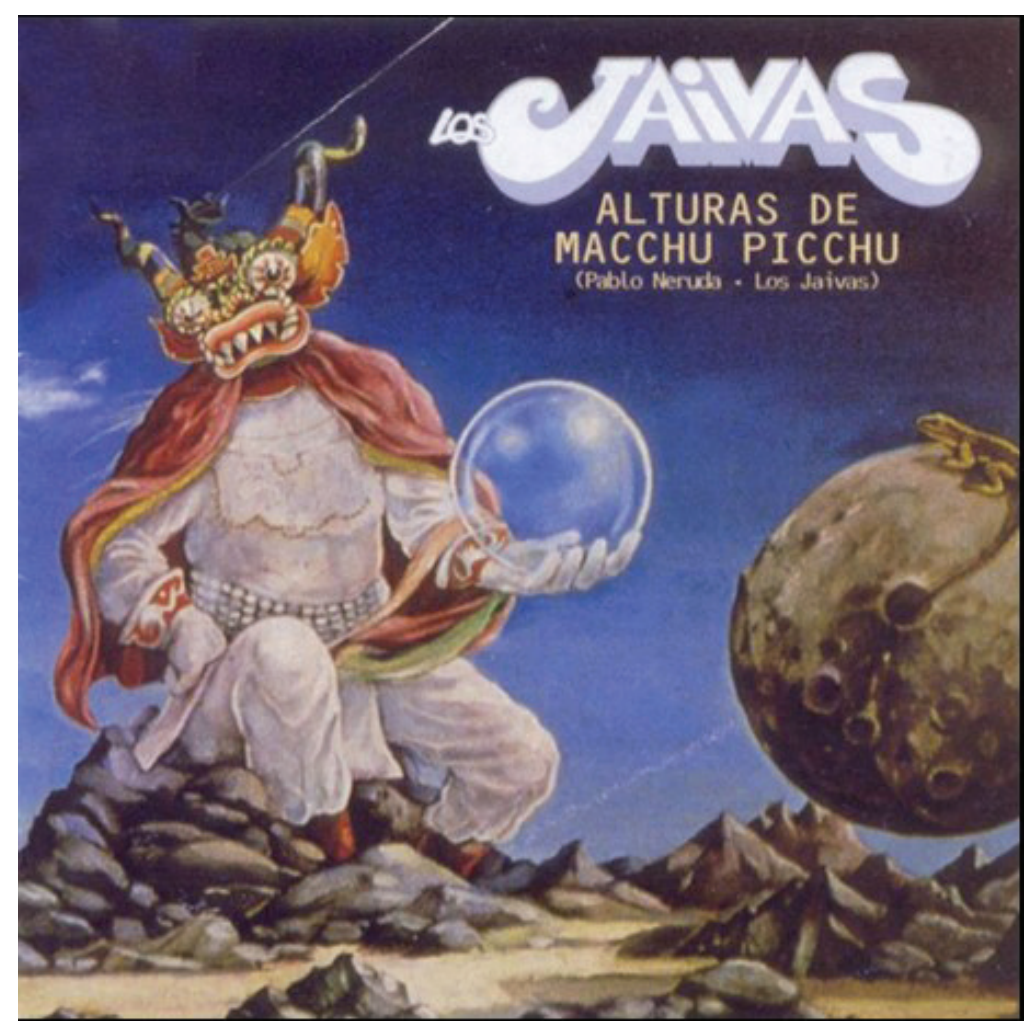

Figura 1 - Capa de Alturas de Macchu Picchu, de Los Jaivas (1981).

18 “Não voltará/tua voz endurecida/Não voltarão/teus olhos perfurados/sobe a nascer comigo, irmão” (tradução minha). 


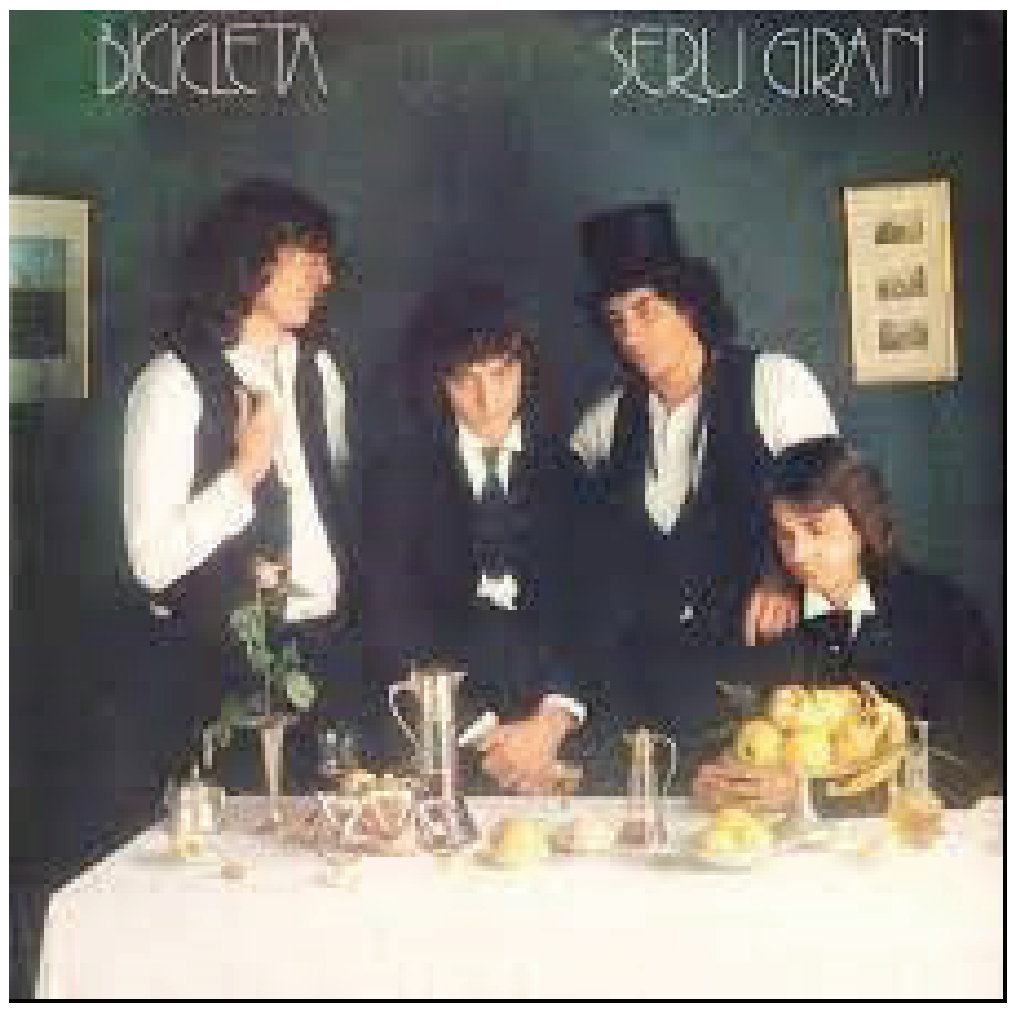

Figura 2: Capa de Bicicleta (1980), de Serú Girán.

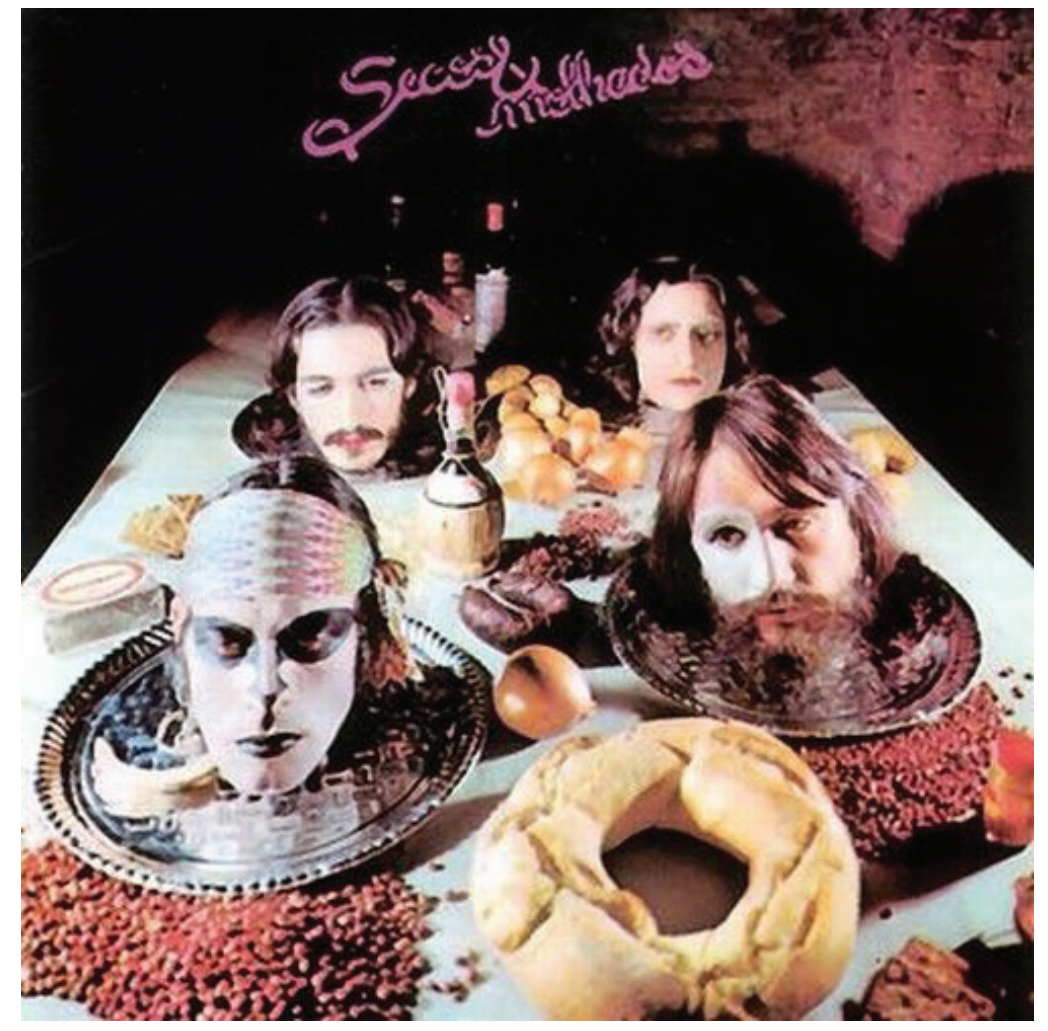

Figura 3: capa de Secos \& Molhados, dos Secos \& Molhados (1973). 


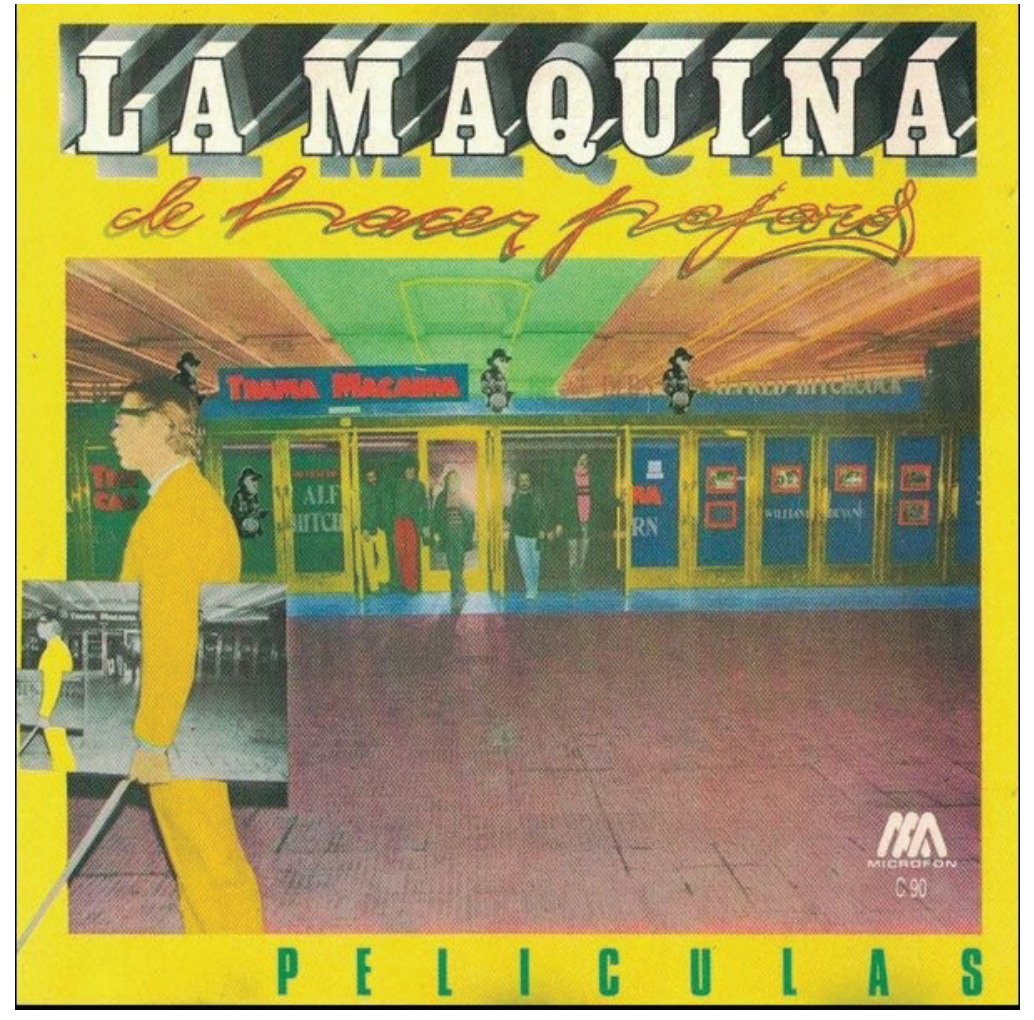

Figura 4: Capa de Películas (1977), de La Máquina de Hacer Pájaros.

\section{Referências Bibliográficas}

ALBIN, Ricardo Cravo. Tropicalismo. In: ALBIN, Ricardo Cravo (org.). Dicionário Houaiss Ilustrado da Música Popular Brasileira. Rio de Janeiro: Paracatu, 2006.

ALEXANDRE, Ricardo. Poder para o povo preto. In: História do Rock, v. 1. 1936/1963. São Paulo: Abril, 2005.

BARCINSKY, André. Rock'n'roll: Um, dois, três, quatro! Superinteressante. São Paulo: Abril, set. 2004.

BAUMAN, Zygmunt. O mal-estar da pós-modernidade. Rio de Janeiro: Zahar, 1998.

CARROLL, Lewis. Alice's adventures in wonderland. New York: Barnes \& Noble, 1994.

DUARTE, Geni Rosa. Acordes precisos e discursos dissonantes: debates estéticos e políticos em torno da Tropicália. Temas \& Matizes. ano V, n. 10. Cascavel, PR: Unioeste, 2001.

FIUZA, Alexandre. As metáforas e a censura ao cancioneiro engajado no Brasil, Portugal e Espanha. Temas \& Matizes. ano V, n. 10. Cascavel, PR: Unioeste, 2001.

FRIEDLANDER, Paul. Rock and roll: Uma história social. 3 ed. São Paulo: Record, 2004. 
LA MÁQUINA DE HACER PÁJAROS. Películas. Buenos Aires: Microfon, 1977.

LONZA, Furio (org.). Quarenta anos de rock: período pré-jurássico (1955-61). São Paulo: 34, 1995.

LOS JAIVAS. Alturas de Macchu Picchu (Rock Andino). São Paulo: Epic, 1981.

MAZZOLENI, Florent. As raízes do rock. São Paulo: Companhia Editora Nacional, 2012.

NAHOUM, Leonardo. Enciclopédia do rock progressivo. Niterói: Rock Symphony, 2005.

PAYTRESS, Mark. History of rock. New York: Parragon, 2011.

ROSA, Fernando. Isso é só o fim? In: História do Rock. v. 1: 1936/1963. São Paulo: Abril, 2005.

STOFFEL, Stephanie Lovett. Lewis Carroll in wonderland: The Life and Times of Alice and her Creator. New York: Abrams, 1997.

SAGIORATTO, Alexandre. Barra Rock: sons da contracultura brasileira das décadas de 1960 e 1970. Passo Fundo: Méritos, 2021.

SECOS \& MOLHADOS. Secos \& Molhados. Rio de Janeiro: Continental, 1973.

SERÚ GIRAN. Bicicleta. Buenos Aires: SG Discos, 1980. 
